\title{
ПРОБЛЕМА ОСВІТНЬОї ЯКОСТІ В СТРАТЕГІЇ РОЗВИТКУ ВИЩОЇ ОСВІТИ В УКРАЇНІ
}

\author{
Пропозиції підгрупі № 10 «Розбудова системи моніторингу і оцінки якості \\ освіти» робочої групи з розроблення проєкту Cтратегії розвитку вищої \\ освіти в Україні на 2021-2031 роки
}

https://doi.org/10.37472/2707-305X-2020-2-2-11-1

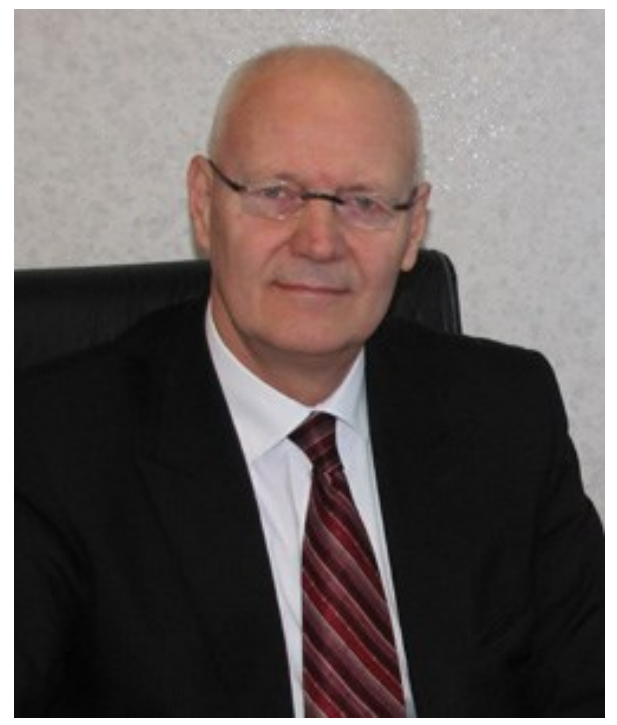

лУгОВиЙ

\section{Володимир Іларіонович}

доктор педагогічних наук, профресор, дійсний член (академік) НАПН України, перший віцепрезидент Національної академії педагогічних наук України, член робочої групи МОН України з розроблення проєкту Cтратегії розвитку вищої освіти в Україні на 2021-2031 роки, м. Київ, Україна

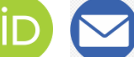

Анотація. На підставі результатів авторських системних досліджень проблем освітньої якості в Україні $і$ світі сорормульовано стратегічно важливі пропозищії для забезпечення і вдосконалення якості вищої освіти. Ідентифіковано причини недостатньої освітньої якості - недосконалість університетської мережі, несформованість системи механізмів моніторингу і оцінювання якості, відсутність профрілю якості вищої освіти. Аргументовано необхідність у практичному забезпеченні та вдосконаленні якості вищої освіти розрізняти і враховувати дуальність категорії якості - мінімально достатню і максимально досконалу, та відповідні механізми моніторингу і оцінювання, а також мотивації якісної освітньої діяльності зобов'язання і заохочення досягнення якості. У пропозиціях акцент зроблено на формуванні в Україні глобально конкурентоспроможної якості, створення університетів світового і субсвітового класу, зокрема шляхом їх укрупнення.

Ключові слова: якість вищої освіти; дуальність якості; забезпечення і вдосконалення якості; механізми моніторингу $і$ оцінювання освітньої якості; профріль якості вищої освіти.

За результатами участі в першому засіданні підгрупи № 10 «Розбудова системи моніторингу і оцінки якості освіти» робочої групи з розроблення проєкту Стратегії розвитку вищої освіти в Україні на 2021-2031 роки (далі - Стратегія), утвореної наказом Міністерства освіти і науки України від 28 липня 2020 р. № 974, запропоновано врахувати наступне.

Перше. Розширити зміст діяльності підгрупи, відповідно уточнивши назву підгрупи (або розділу Стратегії) як «Розбудова системи забезпечення і вдосконалення, моніторингу і оцінювання якості вищої освіти».

Друге. Основними проблемами визнати:

- брак конкурентоспроможної якості вищої освіти в Україні;

- збільшення відставання від світових університетських лідерів і центрів;

- неусвідомлення / слабке знання реального стану вітчизняної вищої освіти та їі адекватності статусу самостійної і самодостатньої конкурентоспроможної країни;

- відсутність об'єктивної, валідної, вірогідної індикації освітньої якості (проблема методології, критеріїв і показників та надійної статистичної інформації). 
Tpemє. Основні причини зазначених проблем:

- недосконалість мережі вищої освіти, ії подрібненість і розпорошеність, деконцентрація людських, фінансових, інформаційних, інфраструктурних ресурсів, профільна неадекватність закладів, надмірне дублювання підготовки;

- несформованість необхідних і достатніх системи/механізмів моніторингу та оцінювання, забезпечення та вдосконалення освітньої якості (далі - система/механізми);

- домінування моністичного підходу до якості (нерозрізнення мінімально достатньої і максимально досконалої якості, забезпечення і вдосконалення якості, мотивації зобов' язання дотримання порогової і заохочення досягнення топової якості).

Четверте. Основні стратегічні принципи розбудови системи/механізмів мають включати:

- самокритичний, системний аналіз освітньої якості та умов ії̈ забезпечення і вдосконалення в контексті дослідницько-інноваційного типу прогресу та конкурентного розвитку;

- створення об'єктивних, валідних, вірогідних, прозорих і зрозумілих системи/механізмів, що адекватні дуальному характеру якості, ії відповідності стандарту-мінімуму та стандарту-максимуму, місійному призначенню університетів та потребам суспільства, громадян, економіки.
П'яте. Основні стратегічні цілі та показники їх досягнення:

- створено систему механізмів моніторингу і оцінювання якості вищої освіти, яка включає національні ліцензійно-акредитаційну, класифікаційно-асоціаційну та рейтингову (інституційну і галузеву) підсистеми; класифікаційно-асоціаційна підсистема передбачає наявність класифікації закладів за рівнем складності та масштабом надання освітніх, освітньо-наукових, наукових акредитованих програм, на кшталт, Класифікації Карнегі, а також лідерської Асоціації українських університетів, за прикладом, Асоціації американських університетів, до якої провідні університети приймаються і виключаються в залежності від якості діяльності;

- визначено інституційний (національний та регіональний) і предметний (за галузями знань) профіль якості вищої освіти;

- чітко відомі інституційні та галузеві закладиаутсайдери і заклади-лідери (країна точно знає свої «Гарвард і Стенфорд», «Кембридж і Оксфорд», «Варшавський і Ягелонський університети» як зразкові центри університетської досконалості);

- кількість закладів вищої освіти шляхом укрупнення скорочена (без зменшення обсягів фінансування на рівні 1,2-1,3 \% ВВП) удвічі (з нинішніх 281 до 140-150);

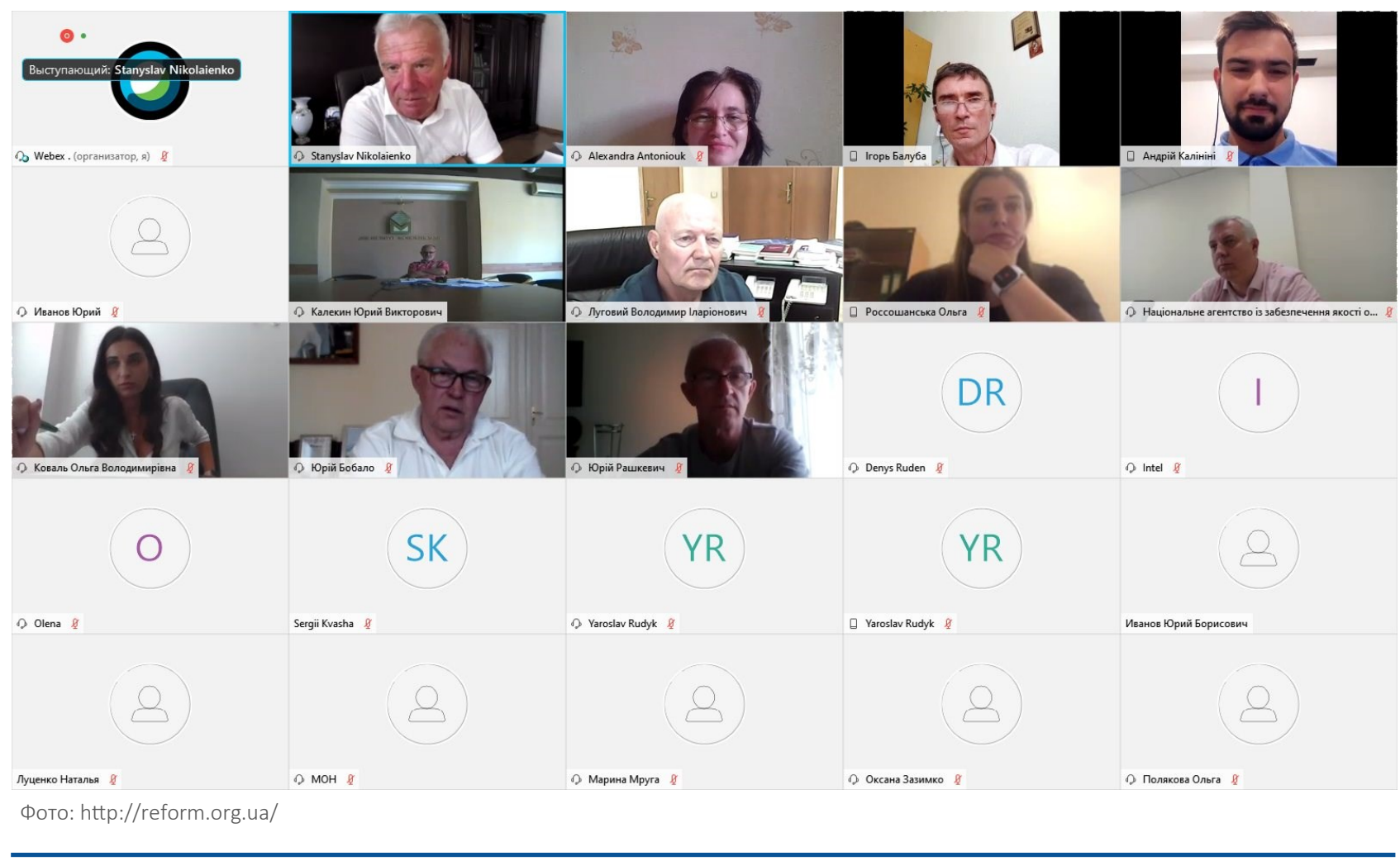


- у країні наявні 2-3 університети світового класу (у групі топ 500 за Шанхайським рейтингом), 4-5 університетів субсвітового класу (кандидатів у світовий клас, група 501-1000), а також університети світового і субсвітового класу у 10-15 \% з 54 предметних галузей Шанхайського рейтингу.

Шосте. Законодавча основа - унормування законом, крім ліцензійно-акредитаційної, також класифікаційно-асоціаційної та, особливо, рейтингової (інституційної та галузевої) підсистем моніторингу та оцінювання якості вищої освіти. Кожна реальна підсистема має бути акредитована (визнана) на державно-громадському рівні.

\section{СПИСОК ВИКОРИСТАНИХ ДЖЕРЕЛ}

Виконання критеріїв надання та підтвердження статусу національного закладу вищої освіти : аналітичний звіт. (2019). Київ: Національне агентство із забезпечення якості вищої освіти. https:// naqa.gov.ua/wp-content/uploads/2019/10/A-2019-120191015-3.pdf

Вища освіта в Україні у 2019 році : статистична інформація. (2020). Київ: Державна служба статистики України. http://www.ukrstat.gov.ua/

Воробйова, О., Дебич, М., Линьова, І., Луговий, В., Оржель, О., Слюсаренко, О., Таланова, Ж., \& Трима, К. (2018). Аналіз провідного вітчизняного та зарубіжного досвіду щодо оцінювання якості вищої освіти в умовах євроінтеграції (частина I) : аналітичні матеріали (В. Луговий, Ж. Таланова, ред.). Київ: ІВО НАПН України. https://bit.ly/2Ctk3Ei

Воробйова, О., Дебич, М., Луговий, В., Оржель, О., Слюсаренко, О., Таланова, Ж., \& Трима, К. (2019). Аналіз провідного вітчизняного та зарубіжного досвіду щодо оцінювання якості вищої освіти в умовах євроінтеграції (частина II) : аналітичні матеріали. (В. Луговий, Ж. Таланова, ред.). Київ: ІВО НАПН України. https://doi.org/10.31874/978-6177486-28-1-2019

Воробйова, О.П., Гриценко, М.В., Луговий, В.І., Оржель, О.Ю., Слюсаренко, О.М., Ставицький, А.В., Таланова, Ж.В., Ткаченко, В.П., \& Трима, К.А. (2017). Світоглядні пріоритети гуманізації вищоі освіти : монографія (В.І. Луговий, Ж.В. Таланова, ред.). Київ: ІВО НАПН України.https://bit.ly/2ZAPRPa

Bcmyn.OCBITA.UA. (2020). https://vstup.osvita.ua/

Державна казначейська служба України. (2020). Річний звіт про виконання Державного бюджету України за 2019 рік. https://www.treasury.gov.ua/ua/filestorage/richnij-zvit-pro-vikonannya-derzhavnogobyudzhetu-ukrayini-za-2019-rik

Закон України. (2014, 1 липня). Про вищу освіmу (1556VII). http://zakon5.rada.gov.ua/laws/show/1556-18

Інформаційна система «Конкурс». (2020). Вступна кампанія 2019 року. http://vstup.info/\#2019
Кабінет Міністрів України. (2017, 22 листопада). Про затвердження Порядку та критеріїв надання закладу вищої освіти статусу національного, підтвердження чи позбавлення цього статусу (912). https://zakon.rada.gov.ua/laws/show/912-2017-п Кабінет Міністрів України. (2018, 14 березня). Про затвердження переліку світових рейтингів університетів для визначення особливої категорії іноземців та осіб без громадянства, які претендують на прачевлаштування в Україні (154-р). http://zakon.rada.gov.ua/laws/show/154-2018-p

Кабінет Міністрів України. (2019, 24 грудня). Про розподіл видатків державного бюджету між закладами вищої освіти на основі показників ї освітньої, наукової та міжнародної діяльності (1146). https://zakon.rada.gov.ua/laws/show/11462019-п

Концептуальні засади реформування публічного фінансування та управління закладами вищої освіти. (2019). https://osvita.ua/vnz/reform/69080/

Луговий, В.І., Слюсаренко, О.М., \& Таланова, Ж.В. (2018а). Нові уроки лідерства для України від Шанхайського рейтингу 2018 року. Педагогіка $i$ психологія. Вісник НАПН України, (3), 5-22.

Луговий, В.І., Слюсаренко, О.М., \& Таланова, Ж.В. (2018b). Світовий досвід для створення національного рейтингу закладів вищої освіти. Педагогіка $i$ психологія. Вісник НАПН України, (2), 5-23.

Міністерство освіти і науки України. (2020, 28 липня). Про утворення робочої групи з розроблення проєкту Cтратегії розвитку вищої освіти України на 2021-2031 роки (974). http://reform.org.ua/

Освіта.иа. (2020). Рейтинги ВН3. https://osvita.ua/vnz/ rating/

Президент України. (2020, 3 червня). Про вдосконалення вищої освіти в Україні (210). https:// www.president.gov.ua/documents/2102020-34045

Lugovyi, V., Orzhel, O., Slyusarenko, O., \& Talanova, Zh. (2018). Education and research duality - the determining characteristic of higher education. Education: Modern Discourses, (1), 71-88. https:// doi.org/10.32405/2617-3107-2018-1-8

Lugovyi, V., Slyusarenko, O. \& Talanova, Zh. (2019). University rating \& development: challenges and opportunities for Ukraine. Education: Modern Discourses, (2), 60-77. https://doi.org/10.32405/26173107-2019-1-8

ShanghaiRanking Consultancy. (2019, August 15). ShanghaiRanking's Academic Ranking of World Universities 2019 Press Release. http:// www.shanghairanking.com/Academic-Ranking-ofWorld-Universities-2019-Press-Release.html

ShanghaiRanking Consultancy. (2020, June 29). ShanghaiRanking's Global Ranking of Academic Subjects 2020 Press Release. http://www.shanghairanking.com/ ShanghaiRankings-Global-Ranking-of-AcademicSubjects-2020-Press-Release.html 


\section{THE PROBLEM OF EDUCATIONAL QUALITY IN THE STRATEGY \\ FOR THE DEVELOPMENT OF HIGHER EDUCATION IN UKRAINE}

Proposals for the Subgroup No 10 "Development of the System of Education Quality Monitoring and Evaluation" of the Working Group on Designing the Draft Strategy for the Development of Higher Education in Ukraine for 2021-2023

\section{Volodymyr Lugovyi}

DSc in Education, Professor, Full Member (Academician) of NAES of Ukraine, First Vice-President, National Academy of Educational Sciences of Ukraine, Member of the Ministry of Education and Science of Ukraine Working Group on Designing the Draft Strategy for the Development of Higher Education in Ukraine for 2021-2023, Kyiv, Ukraine

Abstract. The strategically important proposals for higher education quality assurance and improvement are presented based on the results of the author's systemic research on the problems of educational quality in Ukraine and the world. The reasons for insufficient educational quality are identified, i.e. imperfection of the university network, the system of quality monitoring and evaluation mechanisms is unformed, no higher education quality profile. The need for practical support and improvement of higher education quality to distinguish and take into account the duality of quality - minimally sufficient and maximally perfect, appropriate mechanisms of monitoring and evaluation, motivation for qualitative educational activity - commitments and encouragement to achieve the quality. The emphasis on developing the globally competitive quality, establishing the world-and subworld-class universities in Ukraine, in particular through their consolidation, is made in the proposals.

Keywords: higher education quality; duality of quality; quality assurance and improvement; mechanisms of educational quality monitoring and evaluation; higher education quality profile. 